\title{
Effects of temperature on Vitalograph spirometer readings
}

\author{
WH PERKS, T SOPWITH, D BROWN, CH JONES, M GREEN
}

From the Brompton Hospital and the Department of Physics, Royal Marsden Hospital, London; and the Royal Shrewsbury Hospital, Shrewsbury

ABSTRACT Spirometric variables were obtained from nine symptomless subjects, who performed forced expiratory manoeuvres with three Vitalograph spirometers at three different ambient temperatures $\left(36 \cdot 5^{\circ} \mathrm{C}, 24 \cdot 1^{\circ} \mathrm{C}\right.$, and $\left.-7 \cdot 3^{\circ} \mathrm{C}\right)$ over three days according to a Latin square design. Analysis of variance showed no significant difference between values at different ambient temperatures when measured at ATPS. Correction of the results to BTPS resulted in a significant difference in values at the three ambient temperatures for all measurements other than the $V_{\max }$. The mean error introduced by conversion to BTPS varied from $7 \%$ (SD $5 \%$ ) for the FVC at $24 \cdot 1^{\circ} \mathrm{C}$ to $30 \%(21 \%)$ for $\operatorname{Vmax}_{50}$ at $-7 \cdot 3^{\circ} \mathrm{C}$. Possible explanations for these observations include the increasing compliance of the spirometer bellows with increasing temperature, relatively slow cooling of gases within the spirometer, and a combination of these effects. We conclude that there is no evidence that conversion to BTPS improves the accuracy of measurements made on a Vitalograph spirometer. Further studies on other spirometers are needed to see whether conversion to BTPS is always appropriate.

Hutchinson noticed when using his spirometer that subjects had larger vital capacities in summer than winter and therefore decided to correct for the effects of changes in ambient temperature. ${ }^{1} \mathrm{He}$ chose to correct for all volumes to $60^{\circ} \mathrm{F}\left(15^{\circ} \mathrm{C}\right)$, which was apparently an average indoor temperature in London at that time. Because of this observation it has become accepted practice to convert volumes from the temperature and pressure around the recording equipment to a standard condition, which for most purposes is that obtaining in the lung. ${ }^{2}$ Because we were engaged in epidemiological surveys using the Vitalograph spirometer in different ambient conditions we wondered whether this practice was valid. We have therefore studied the effects of temperature on Vitalograph spirometer readings.

\section{Methods}

To determine the effect of different ambient temperatures on spirometric variables, three groups of three young symptomless subjects performed three forced vital capacity manoeuvres into each of three Vitalograph spirometers at three ambient tempera-

Address for reprint requests: Dr WH Perks, Clinic 5, Royal Shrewsbury Hospital, Mytton Oak Road, Shrewsbury SY3 8XF.

Accepted 25 April 1983 tures on three consecutive days. The Vitalograph spirometer measures volume by means of a wedge- $\overrightarrow{\vec{P}}$ type bellows made of plasticised PVC. The volume expired is displayed against time on a chart, which is carried on a moving platform. Each spirometer was assessed in a room at $24.1^{\circ} \mathrm{C}\left(\mathrm{SD} 0.5^{\circ} \mathrm{C}\right.$ ) (respiratory physiology laboratory), $36.5^{\circ} \mathrm{C}\left(0.6^{\circ} \mathrm{C}\right)$ (bacterio- 응 logy hot room), and $-7 \cdot 3^{\circ} \mathrm{C}\left(0.7^{\circ} \mathrm{C}\right.$ ) (deep freeze at Smithfield meat market used for storing 500 tons $(63500 \mathrm{~kg}$ ) of frozen meat). Each instrument was left to equilibrate with the ambient temperature $\delta$ overnight before measurements were made. The subjects themselves were exposed to the high and 0 low ambient temperatures for only a few seconds? before starting the FVC manoeuvre but they inspired from the ambient air. The orders of blowing $\underset{\mathrm{N}}{\mathrm{N}}$ and placing of the spirometers were randomised for $\sigma$ each day and the study was set up as a Latin square. N

The results were recorded on Vitalograph charts, Nㅓㅇ numbered, and subsequently analysed blind by a 0 single observer. The FVC was measured at plateau and flow rates at $75 \%, 50 \%$, and $25 \%$ of the vital $\frac{C}{\Phi}$ capacity were measured from sloped lines drawn $\stackrel{9}{\rightleftharpoons}$ tangentially to the spirograph tracing. Spirometric 0 values recorded at $24.1^{\circ} \mathrm{C}$ and $-7.3^{\circ} \mathrm{C}$ were ${ }^{\circ}$ expressed as percentages of those obtained at $\stackrel{\odot}{\stackrel{\mathrm{Q}}{\mathrm{Q}}}$ $36 \cdot 5^{\circ} \mathrm{C}$. The significance of differences was tested by analysis of variance. 
Table 1 Spirometric values obtained at $24 \cdot 1^{\circ} \mathrm{C}$ and $-7.3^{\circ} \mathrm{C}$ expressed as percentages of those obtained at $36.5^{\circ} \mathrm{C}$ when measurements were made at ATPS and after conversion to BTPS in nine subjects using three spirometers

\begin{tabular}{|c|c|c|c|c|}
\hline & & $\frac{\text { Value at } 24 \cdot 1^{\circ} \mathrm{C} C}{\text { Value at } 36 \cdot 5^{\circ} \mathrm{C}} \times 100$ & $\frac{\text { Value at }-7.3^{\circ} \mathrm{C}}{\text { Value at } 36.5^{\circ} \mathrm{C}} \times 100$ & \\
\hline $\begin{array}{l}\text { FEV }_{1} \\
\mathrm{FEV}_{3} \\
\text { FVC } \\
\dot{V}_{\mathrm{max}_{\text {ss }}} \\
\dot{V}_{\max _{\text {s0 }}} \\
\dot{V}_{\max _{25}}\end{array}$ & $\begin{array}{l}\text { ATPS } \\
\text { BTPS } \\
\text { ATPS } \\
\text { BTPS } \\
\text { ATPS } \\
\text { BTPS } \\
\text { ATPS } \\
\text { BTPS } \\
\text { ATPS } \\
\text { BTPS } \\
\text { ATPS } \\
\text { BTPS }\end{array}$ & $\begin{array}{l}101 \pm 5 \\
109 \pm 5 \\
100 \pm 4 \\
107 \pm 4 \\
100 \pm 4 \\
107 \pm 5 \\
101 \pm 12 \\
109 \pm 13 \\
102 \pm 15 \\
110 \pm 17 \\
105 \pm 18 \\
113 \pm 19\end{array}$ & $\begin{array}{l}103 \pm 6 \\
128 \pm 7 \\
103 \pm 6 \\
127 \pm 7 \\
103 \pm 5 \\
128 \pm 7 \\
104 \pm 11 \\
130 \pm 13 \\
104 \pm 17 \\
130 \pm 21 \\
102 \pm 16 \\
127 \pm 20\end{array}$ & $\begin{array}{l}\text { NS } \\
<0 \cdot 001 \\
\text { NS } \\
<0 \cdot 001 \\
\text { NS } \\
<0 \cdot 001 \\
\text { NS } \\
<0 \cdot 025 \\
\text { NS } \\
<0 \cdot 05 \\
\text { NS } \\
\text { NS }\end{array}$ \\
\hline
\end{tabular}

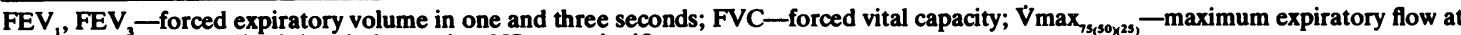
$75 \%$ (or $50 \%$ or $25 \%$ ) of the vital capacity; NS-not significant.

\section{Results}

The results are shown in table 1 . There was no significant difference between any of the spirometric variables at the three different temperatures when measured at ATPS and there were no significant between-machine differences or between-day diferences and no interactions. Converting the spirometric variables to BTPS resulted in a significant difference in values at the three different ambient temperatures for all measurements other than $V \max _{25}$ (maximum expiratory flow at $25 \%$ of vital capacity), where there was very large variability.

\section{Discussion}

Although it has become standard practice to correct for ambient temperature little direct experimental work has been reported on the value of this correction. Gardner and his colleagues studied the effects of heated and humidified air on metal volume spirometers. ${ }^{3}$ By pumping 6 litres of warm $\left(37^{\circ} \mathrm{C}\right)$, humidified $(100 \%$ saturated) air at $12.4 \mathrm{l} / \mathrm{s}$ into a Stead Wells spirometer they found an overshoot of $250 \mathrm{ml}$ and a time constant of $1.4 \mathrm{~s}$ with a one-hose system. Using a forced vital capacity of warm humidified air generated by a computerised system, they found an overshoot of $100 \mathrm{ml}$ at $1.4 \mathrm{~s}$ with an Ohio spirometer. They concluded that gases entering volume-measuring devices cool very rapidly and that temperature correction is thus justified. They did not, however, report observations on spirometers with plastic bellows, nor did they study effects on varying ambient temperatures.

Studying the Vitalograph spirometer, we found that there was no significant difference between measurements at different ambient temperatures when volume and flow were measured directly. The "correction" of measurements to BTPS, however, generated significant errors, varying from $7 \%$ to $30 \%$. These observations were made under extreme conditions to amplify any errors, although in a pilot study comparing $24^{\circ} \mathrm{C}$ with $7^{\circ} \mathrm{C}$ similar results were obtained. There are several explanations which may explain the independence of Vitalograph readings from ambient temperature.

There was no reason to suspect that the different ambient conditions affected the subjects. Identical clothing was worn for each FVC manoeuvre and each subject spent minimal time at the extreme temperatures. The purposes of the trial was not explained to the subjects and the results were analysed blind.

It is possible that the characteristics of the spirometer explain the observations. The gas expired into the spirometer may cool relatively slowly because of the low thermal conductivity of the bellows and tubing of this type of spirometer. At 10 seconds the external temperature of the mouthpiece tubing assessed with a thermographic camera (Aga thermovision, Model 680 Medical) is higher than the ambient temperature (fig). Alternatively, the bellows of the spirometer may become more compliant with increasing temperature. As the temperature rises more of the volume is accommodated in horizontal distension of the bellows, leaving less vertical displacement. ${ }^{4}$ Indeed, a combination of these explanations may be correct.

As most respiratory laboratories at present correct results to BTPS (although in many this may be only a token gesture, all values being multiplied by 1.05 or 1.1 ), why bother to change routine practice? If measurements are made with a Vitalograph spirometer in different ambient temperatures and converted to BTPS, then the readings obtained at low ambient temperatures would be disproportionately high. Conceivably therefore spirometric data obtained from epidemiological surveys of similar ethnic groups at different ambient temperatures 

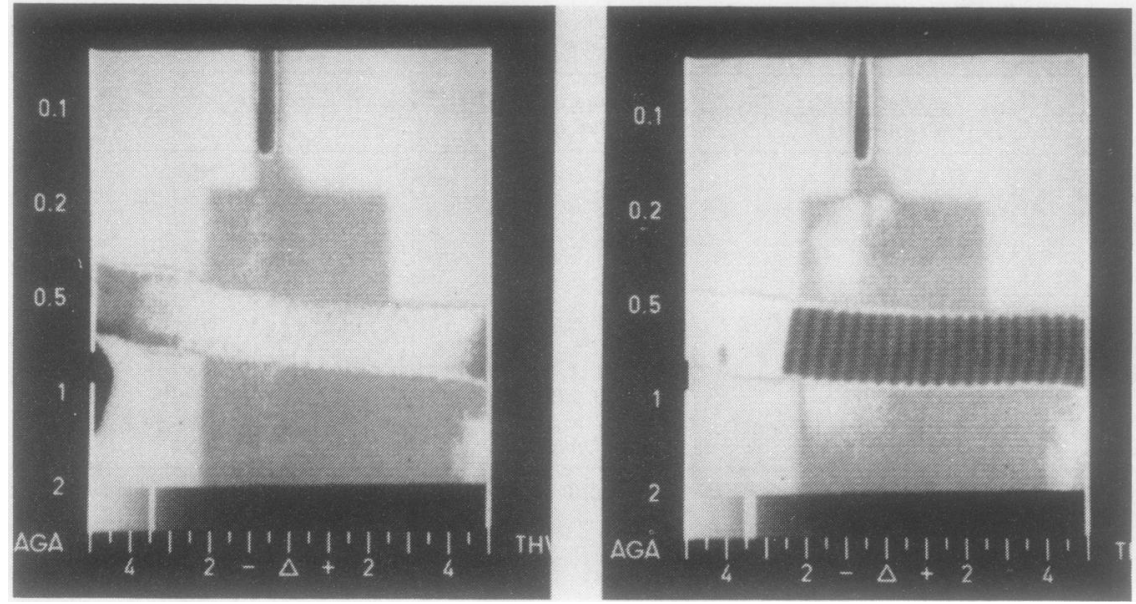

Thermographic photographs of the mouthpiece tubing before and 10 seconds after the beginning of a forced vital $\vec{\circ}$ capacity manoeuvre by a normal subject. The external temperature is hotter (darker) at 10 seconds than before the FVC manoeuvre. might differ. Table 2 compares the mean $\mathrm{FEV}_{1}$ and FVC of similar ethnic groups in different countries. The values obtained in temperate conditions were higher than those obtained in presumably tropical conditions; both were corrected to BTPS, and removal of the correction would tend to reduce the differences. Although these groups may not be directly comparable and the significance of the differences is uncertain, spirometric values obtained for similar ethnic groups in different countries appear to be different and this could be a direct consequence of "correction" of lung volumes by conversion to BTPS.

This paper asks more questions than it answers. The heat physics of spirometers is clearly complex and the performance of different instruments under different ambient conditions may be highly dependent on materials and manufacturing techniques. Further studies are needed on the effect of temperature on this spirometer and on others of different design. We conclude that, for the sake of simplicity and uniformity, measurements made with the Vit-

Table 2 Spirometric variables for men of similar race but from different countries derived from regression equations in published reports: results corrected to BTPS and to age 37 years and height $1.69 \mathrm{~m}$

\begin{tabular}{|c|c|c|c|}
\hline & $\begin{array}{l}\text { Presumed } \\
\text { temperate } \\
\text { conditions }\end{array}$ & \multicolumn{2}{|c|}{$\begin{array}{l}\text { Presumed tropical } \\
\text { conditions }\end{array}$} \\
\hline $\begin{array}{l}\text { FEV (1) } \\
\text { FVC }^{\prime}(1) \\
\text { FVC (1) }\end{array}$ & $\begin{array}{l}\text { Pakistanis } \\
\text { in UK } \\
3.35 \\
3 \cdot 93 \\
\text { Negroes in } \\
\text { USA }^{8} \\
4 \cdot 15\end{array}$ & $\begin{array}{l}\text { Pakistanis } \\
\text { in Pakistan } \\
\text { 3.03 } \\
3.91 \\
\begin{array}{ll} & \\
& \text { Neg } \\
& \text { Guy } \\
& 3.73\end{array}\end{array}$ & $\begin{array}{l}\text { Asian Indians } \\
\text { in Guyana? } \\
2.89 \\
3.56 \\
\text { es in } \\
a^{7}\end{array}$ \\
\hline
\end{tabular}

alograph spirometer should not be converted to BTPS.

We wish to thank Drs RB Cole, TB Stretton, and D Denison for encouragement and advice; the staff of the chest unit, St Bartholomews Hospital; Miss Heather Whippy and Miss Alison Evans for secretarial help; and Miss $M$ Rehan for statistical advice. We would also like to thank Mr N Dobbs and the staff of Garnham Bros Ltd for allowing us to use their cold storage room.

\section{References}

${ }^{1}$ Hutchinson J. Lecture on vital statistics, embracing an account of a new instrument for detecting the presence of disease in the system. Lancet 1844;1:567-70.

${ }^{2}$ Cotes JE. Lung function: assessment and application in medicine. 4th ed. Oxford: Blackwell Scientific Publications, 1979:16-8.

${ }^{3}$ Gardner RM, Hankinson JL, West BJ. Evaluating commercially available spirometers. Am Rev Respir Dis 1980;121:73-82.

${ }^{4}$ Van Fleet D, Buist AS, Nagy JM. Temperature sensitivity and the Vitalograph spirometer. Respiratory News Bulletin 1977;19:3.

${ }^{5}$ Malik MA, Moss E, Lee WR. Prediction values for the ventilatory capacity in male West Pakistani workers in the United Kingdom. Thorax 1972;27:611-9.

${ }^{6}$ Williams DE, Drew Miller R, Taylor WF. Pulmonary function studies in healthy Pakistani adults. Thorax 1978;33:243-9.

${ }^{7}$ Miller GJ, Ashcroft MT, Swan AV, Beadnell HMSG. Ethnic variation in forced expiratory volume and forced vital capacity of African and Indian adults in Guyana. Am Rev Respir Dis 1970;102:979-81.

8 Abramowitz S, Leiner GC, Lewis WA, Small MJ. Vital capacity in the Negro. Am Rev Respir Dis 1965;92:287-92. 